\title{
Athabaskan brainstem dysgenesis syndrome
}

INSERM

\section{Source}

INSERM. (1999). Orphanet: an online rare disease and orphan drug data base.

Athabaskan brainstem dysgenesis syndrome. ORPHA:69739

Ahabaskan brainstem dysgenesis is characterised by deafness, central hypoventilation, congenital ocular paralysis and developmental retardation. Cardiac anomalies and paralysis of the vocal chords may also be present. Six cases have been reported so far. Transmission is thought to be autosomal recessive. 